\title{
Seed germination of Agave species as influenced by substrate water potential
}

\author{
Hugo M Ramírez-Tobías ${ }^{1,2 *}$, Cecilia B Peña-Valdivia2 ${ }^{*}$, Carlos Trejo ${ }^{2}$, J Rogelio Aguirre $\mathrm{R}^{3}$ and Humberto Vaquera $\mathrm{H}^{4}$
}

\begin{abstract}
Background: Plants of Agave spp. perform Crassulacean acid metabolism (CAM) and are highly drought-tolerant, but little is known concerning seed germination under low water availability. The aim of this study was to assess the effect of substrate water potential $\left(\Psi_{w}\right)$ on seed germination and contrast hydrotime parameters of seven valuable and commercially-important Agave species from different geographical distributions and climatic regions of Mexico. Our hypothesis was that seed germination of Agave species is not affected by low water availability independently of seed biomass and the climate of their distribution area.
\end{abstract}

Results: Seed germination (at $25^{\circ} \mathrm{C}$ and in the dark) between 85 and $100 \%$ for all species occurred within $80-180 \mathrm{~h}$ at $-0.03 \mathrm{MPa}$ and $250-430 \mathrm{~h}$ at $-1.0 \mathrm{MPa}$. Seed germination at $-1.5 \mathrm{MPa}$ declined to less than $50 \%(p<0.05)$ for $\mathrm{A}$. asperrima and $A$. cupreata but did not change significantly for $A$. americana var. marginata, A. lechuguilla and $A$. striata, although they showed the lowest mean base water potential (-2.01 to $-2.64 \mathrm{MPa})$. Seed germination of $40 \%$ Agave species, from arid and semi-arid climates in this study, was not affected by the lower $\psi_{w}$.

Conclusion: Germination of seeds of Agave species is moderately affected by low water availability, is partially dependent of their ecological distribution, and is independent of seed mass.

Keywords: Base water potential, CAM, Drought, Germination, Hydrotime model, Maguey

\section{Background}

Approximately 74. Agave species and 28 intraspecific taxa have been used in Mexico as human food, fodder, raw material for fermented beverages and to obtain fibers; at least 48 of these species are currently used to produce spirits called "tequila", "mezcal", "bacanora" and other distilled with economic importance [1]. The agave plant is described as a monocarpic perennial monocot that produces an inflorescence only once towards the end of its long life cycle. Each plant produces several hundred seeds and it has been demonstrated for a number of Agave species and genotypes that a large proportion of these seeds are viable [1,2]. Agave plants reproduce both sexually and asexually, but they commonly propagate asexually via rhizomes and bulbils in the wild [3]; this propagation favours successful seedling establishment by initial dependence on the mother plant.

\footnotetext{
* Correspondence: hugo.ramirez@uaslp.mx; cecibetipv@gmail.com

${ }^{1}$ Facultad de Agronomía, Universidad Autónoma de San Luis Potosí, Carretera San Luis Potosí - Matehuala km 14.5, Ejido Palma de la Cruz, Soledad de Graciano Sánchez, San Luis Potosí 78321, México

²Botánica, Campus Montecillo, Colegio de Postgraduados, Carretera México-Texcoco km 36.5, Texcoco, Estado de México CP 56230, México Full list of author information is available at the end of the article
}

Agave species are Crassulacean acid metabolism (CAM) plants distributed throughout a wide variety of environments, although a large number of them are found in mesophyte communities [4]; moreover, they tolerate high heat and dry conditions and efficiently produce a large biomass in these environments [5], where few commercial crops can grow. It has also been shown that after germination under optimal conditions, seedlings of A. salmiana can grow on a substrate with a water potential $\left(\Psi_{\mathrm{W}}\right)$ of $-2.5 \mathrm{MPa}$ [6] and young and adult plants of A. salmiana and $A$. angustifolia ssp. tequilana maintain active photosynthetic pathway after six months without water, and even throughout the whole dry season $[7,8]$. It has also been observed that root and leaf growth of young A. salmiana plants is affected by frequent irrigation [8]. In addition, the diversity of Agave species and environments where they are distributed show an array of specific physiological responses associated with the climate where these plants naturally grow. This evidence suggests that agave seed germination, in addition to other physiological processes, might develop properly in conditions which are suboptimal for other species. 


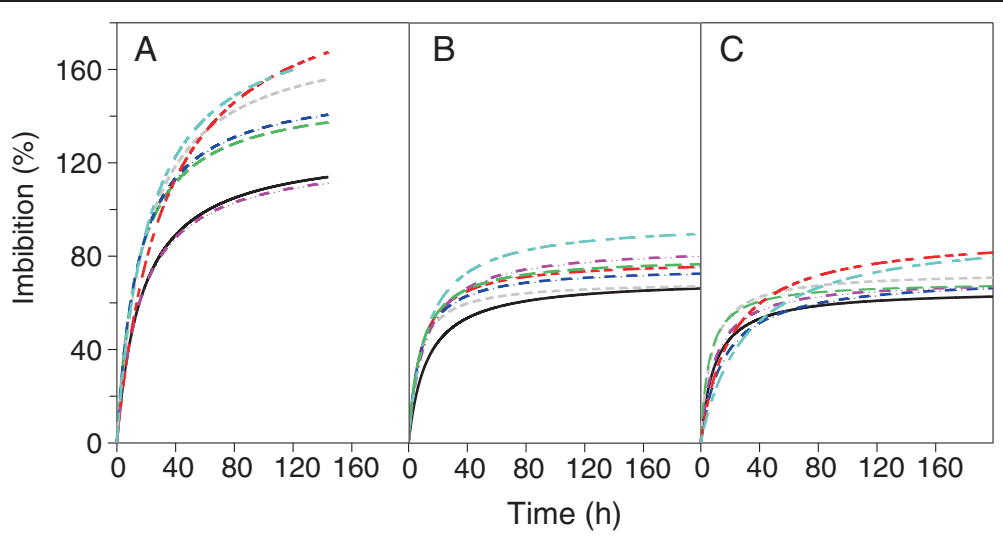

Figure 1 Calculated time-courses of cumulative seed water uptake of Agave spp. at $25^{\circ} \mathrm{C}$, in the dark, and in substrate water potentials of -0.03 (A), -1.0 (B) and -1.5 MPa (C). A. americana var. marginata (black line), A. asperrima (red line), A. cupreata (green line), A. duranguensis (gray line), A. lechuguilla (dark blue line), A. salmiana (pink line) and A. striata (light blue line); $\mathrm{n}=50$.

Germination is affected by intrinsic (species and seed size) and environmental (temperature and water availability) factors; however, the seed germination of species adapted to dry environments and cultivars selected for drought tolerance are less affected by low substrate $\Psi_{\mathrm{W}}$ than those adapted to wet environments or classified as drought-sensitive $[9,10]$. The hydrotime model has been used to quantify the effect of substrate $\Psi_{\mathrm{W}}$ on seed germination. The parameters that describe this model allow quantification of the response of a seed germination population to the substrate $\Psi_{\mathrm{W}}$ and its biological variation [11-13] and are also useful in understanding some of the ecological relationships between plant species $[9,14,15]$.

The aim of this study was to assess the effect of substrate $\Psi_{\mathrm{W}}$ on seed germination and contrast hydrotime parameters of seven valuable and commercially-important Agave species, with a long history of human usage and from different geographical distributions and climatic regions of Mexico. Our hypothesis was that seed germination of Agave species is not affected by low water availability independently of seed biomass and the climate of their distribution area.

\section{Results}

\section{Seed water uptake}

Seed water uptake with maximum water availability varied significantly $(\mathrm{p}<0.05)$ among species (Figure 1$)$. Imbibition by $A$. cupreata and $A$. duranguensis was $20 \%$ higher than for $A$. americana and A. salmiana during first $12 \mathrm{~h}$ of germination at $-0.03 \mathrm{MPa}$, at $\Psi_{\mathrm{W}}$ lower than $-0.03 \mathrm{MPa}$ decreased significantly (between $42 \%$ and 67\%) for all species, and with the exception of $A$. americana, A. cupreata and $A$. duranguensis decreased linearly. Also, of these three species, initial seed water uptake at -1.5 was not significantly different $(\mathrm{p}>0.05)$ than at $-1.0 \mathrm{MPa}$ (Figure $2 \mathrm{~A}$ ).

Differences and similarities in seed water uptake changed with time and with substrate $\Psi_{\mathrm{W}}$. Maximum seed

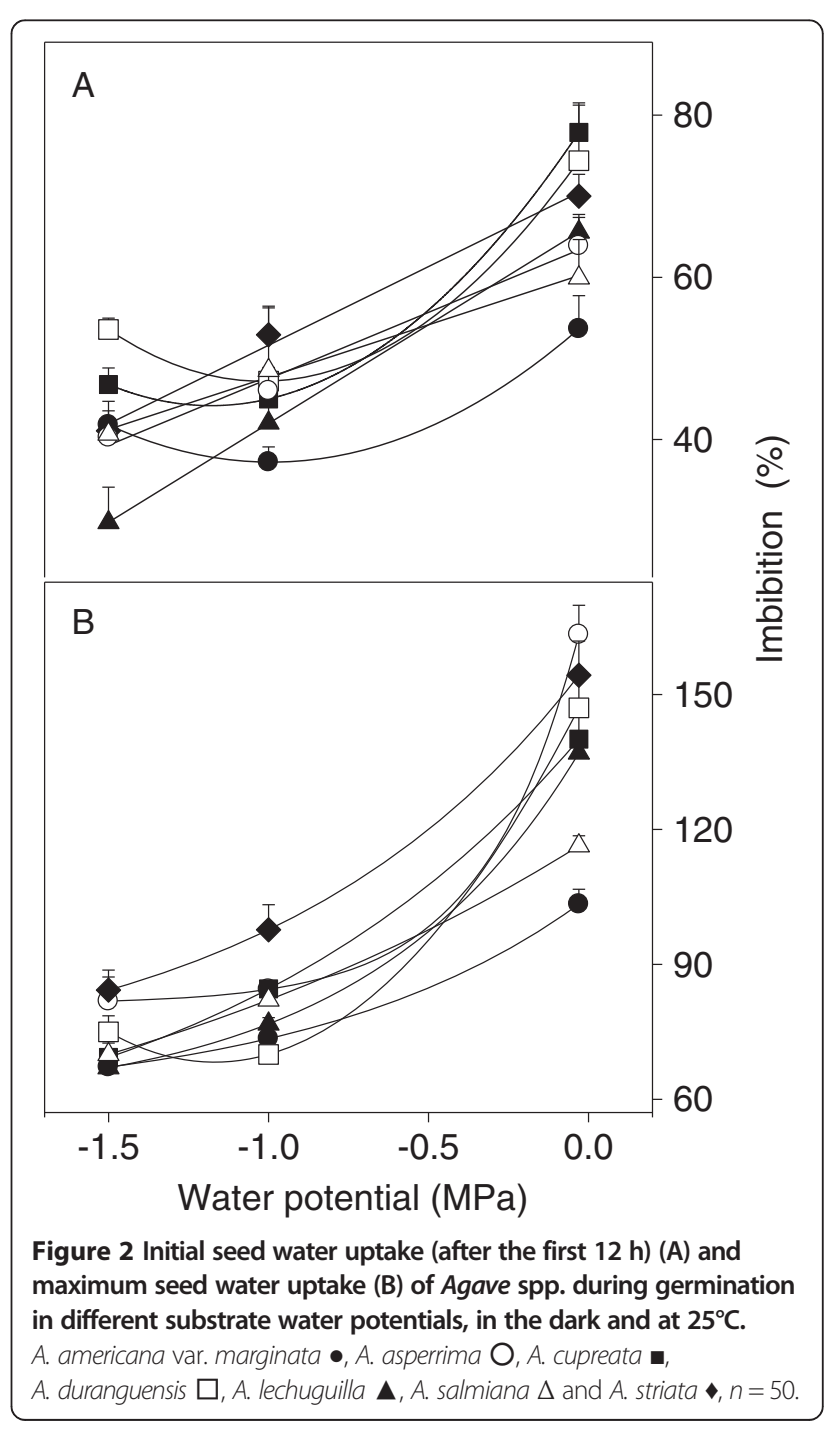


water uptake of $A$. asperrima and A. striata was significantly higher (165\%) than for the other five species and strongly contrasted with that for A. americana and $A$. salmiana, which had the lowest water uptake (100 and $115 \%)(\mathrm{p}<0.05)$ of all seven species at a $\Psi_{\mathrm{W}}$ of $-0.03 \mathrm{MPa}$ (Figures 1A and 2B). The initial accelerated water uptake up to maximum germination, was on average $43 \%$ lower $(p<0.05)$ at both low $\Psi_{\mathrm{W}}(40 \mathrm{~h})$ than at $-0.03 \mathrm{MPa}(70 \mathrm{~h})$ (Figure 1A-C). Maximum seed water uptake of all Agave species reduced significantly in a non-linear fashion $(50 \%$ on average) with lower $\Psi_{\mathrm{W}}$ (Figure 2B) and the large differences observed at $-0.03 \mathrm{MPa}$ among species almost disappeared at -1.0 and $-1.5 \mathrm{MPa}$ (Figure $1 \mathrm{~A}-\mathrm{C}$ ). In general, maximum seed water uptake of $A$. striata and $A$. asperrima was among the highest at all three $\Psi_{\mathrm{W}}$, whereas that of $A$. americana was among the lowest. Other differences in seed water uptake were that only $A$. asperrima reached similar $(\mathrm{p}>0.05)$ maximum seed water uptake at $-1.0 \mathrm{MPa}$ and $-1.5 \mathrm{MPa}$; and only $A$. duranguensis reached a higher $(\mathrm{p}<0.05)$ maximum seed water uptake at $-1.5 \mathrm{MPa}$ than at $-1.0 \mathrm{MPa}$ (Figure 2B).

\section{Radicle emergence}

All seven Agave species lacked significant seed dormancy and mean cumulative germination (radicle emergence) at $-0.03 \mathrm{MPa}$ was $84-100 \%$ in 80 to $180 \mathrm{~h}$, depending

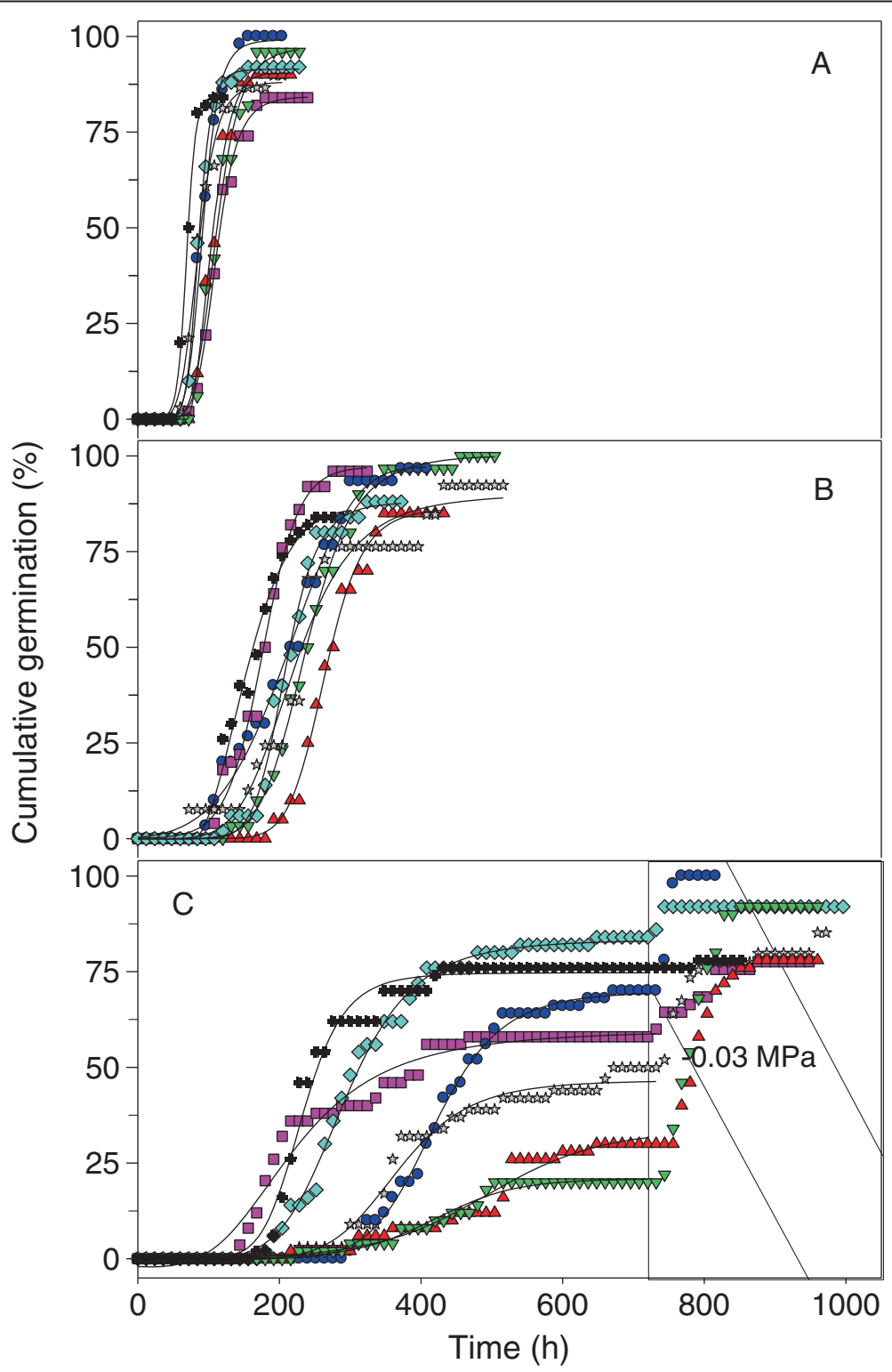

Figure 3 Time-course of cumulative germination of Agave spp. seeds in substrate at $-0.03 \mathrm{MPa}(\mathrm{A}),-1.0 \mathrm{MPa}(\mathrm{B})$, and $-1.5 \mathrm{MPa}$ followed by $-0.03 \mathrm{MPa}$ (shaded area; $\mathrm{C}$ ), in the dark and at $25^{\circ} \mathrm{C}$. A. americana var. marginata (crosses), A. asperrima (red triangles), A. cupreata (green triangles), A. duranguensis (gray stars), A. lechuguilla (blue circles), A. salmiana (pink squares) and A. striata (blue diamonds), $\mathrm{n}=50$. 
on the species (Figure 3A). On average, germination at $-0.03 \mathrm{MPa}$ started at $72 \mathrm{~h}$ and significantly increased almost each $12 \mathrm{~h}$, up to $120 \mathrm{~h}$. Maximum cumulative germination was similar at $\Psi_{\mathrm{W}}$ of $-1.0 \mathrm{MPa}$ and at $-0.03 \mathrm{MPa}$, but the time taken to reach the maximum increased more than two-fold (Figure 3A-B). On average, germination at $-1.0 \mathrm{MPa}$ started after $132 \mathrm{~h}$ and significantly rose for $240 \mathrm{~h}$, but the cumulative germination increase was significantly each 12 or $24 \mathrm{~h}$, and was slower than at $-0.03 \mathrm{MPa}$. In contrast, a $\Psi_{\mathrm{W}}$ of $-1.5 \mathrm{MPa}$ reduced on average $50 \%$ the maximum cumulative germination of all species in comparison with -0.03 and $-1.0 \mathrm{MPa}$, except for $A$. striata and A. americana (Figure $3 \mathrm{C}$ ). Germination at $-1.5 \mathrm{MPa}$ started after $209 \mathrm{~h}$, but was significantly different from the starting level until $228 \mathrm{~h}$ (almost zero), this $\Psi_{\mathrm{W}}$ caused significantly rise of germination at 12,24 and $36 \mathrm{~h}$ periods, but this rise was slower than at -1.0 and $-0.03 \mathrm{MPa}$.

The rate of germination at $\Psi_{\mathrm{W}}$ between -0.03 and $-1.5 \mathrm{MPa}$ decreased linearly $(\mathrm{p}<0.05)$ for all species (on average from 0.26 to 0.06 seeds $\left.\mathrm{d}^{-1}\right)$, however, the decrease in A. salmiana was the lowest ( 0.2 to $0.1 \mathrm{~d}^{-1}$; Figure 4$)$. The hydrotime parameters of $A$. salmiana were notable among all species as it had the highest $\theta_{\mathrm{H}}$ and $\sigma_{\Psi \mathrm{b}}$ and the lowest $\Psi_{\mathrm{b}(50)}$. All species showed a relatively similar $\theta_{\mathrm{H}}$ between 140 and 190 (Table 1), except for A. salmiana.

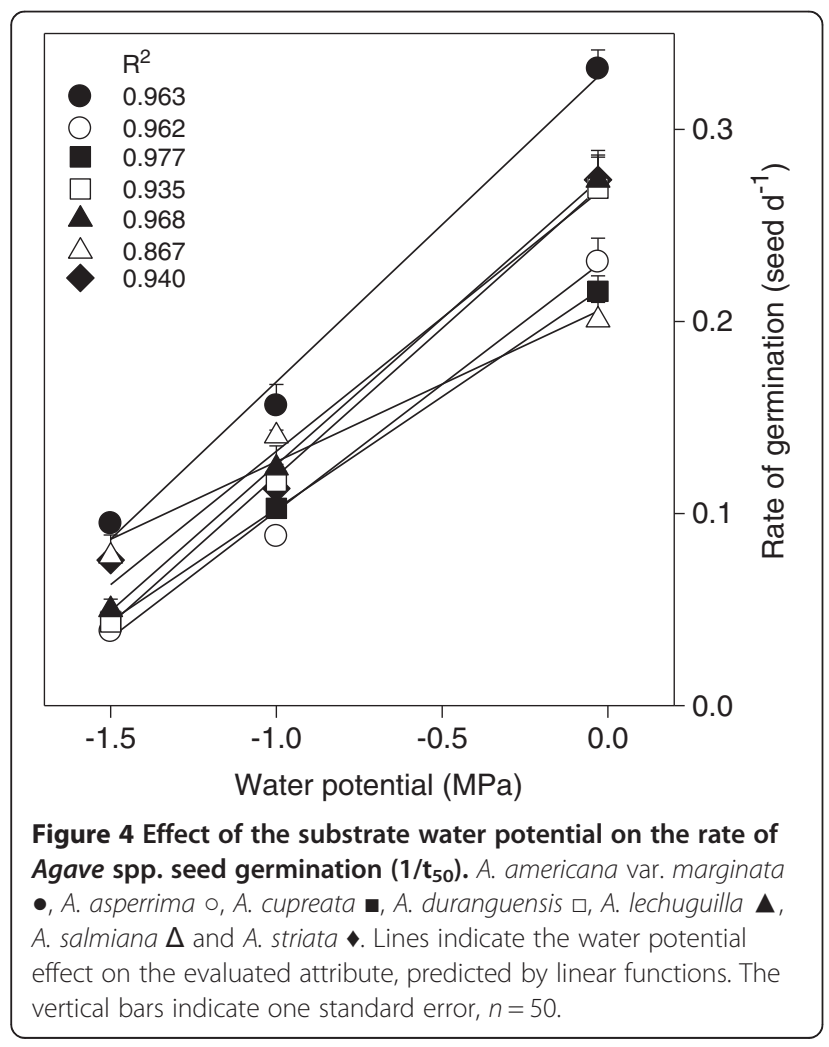

Table 1 Parameters of the hydrotime model for seed germination of seven Agave species under three substrate water potentials $(-0.03,-1.0$ and $-1.5 \mathrm{MPa})$

\begin{tabular}{lcccc}
\hline Species & $\boldsymbol{\theta}_{\mathbf{H}}(\mathbf{M P a} \mathbf{h})$ & $\boldsymbol{\Psi}_{\mathbf{b}(\mathbf{5 0})}(\mathbf{M P a})$ & $\boldsymbol{\sigma}_{\boldsymbol{\psi}_{\mathbf{b}}}(\mathbf{M P a})$ & $\mathbf{r}^{\mathbf{2}}$ \\
\hline $\begin{array}{l}\text { A. americana var. } \\
\text { marginata }\end{array}$ & 142 & -2.01 & 0.44 & 0.823 \\
A. asperrima & 158 & -1.58 & 0.37 & 0.881 \\
A. cupreata & 190 & -1.82 & 0.46 & 0.814 \\
A. duranguensis & 137 & -1.68 & 0.58 & 0.775 \\
A. lechuguilla & 153 & -1.84 & 0.36 & 0.892 \\
A. salmiana & 282 & -2.64 & 0.81 & 0.768 \\
A. striata & 176 & -2.02 & 0.41 & 0.829 \\
\hline
\end{tabular}

$\theta_{\mathrm{H}}$ : hydrotime constant; $\psi_{\mathrm{b}(50)}$ : base water potential; $\sigma_{\psi_{\mathrm{b}}}$ : standard deviation of $\psi_{\mathrm{b}(50)} ; r^{2}$ : determination coefficient.

\section{Recovery of germination}

A large proportion (20-80\%) of seeds of several species did not germinate after a relatively long period $(732 \mathrm{~h}$ ) at $\Psi_{\mathrm{W}}$ of $-1.5 \mathrm{MPa}$. However, germination continued after $12-48 \mathrm{~h}$ when these seeds were transferred to a substrate with a $\Psi_{\mathrm{W}}$ of $-0.03 \mathrm{MPa}$. Thus, A cupreata, A. striata, A. duranguensis and A. lechuguilla reached the second final maximum cumulative germination (85-100\%) similar to that at -1.0 and $-0.03 \mathrm{MPa}(\mathrm{p}>0.05)$. Likewise, germination of the other three species also increased up to $80 \%$ after being transferred to the highly hydrated substrate (Figure 3C). Under these conditions, most Agave species tolerated slow seed water uptake and survived for more than $30 \mathrm{~d}$ with $70 \%$ hydration without damage.

\section{Discussion}

Seed water uptake

Germination phases I and II for the seven species (Figure 1) were similar to those of dried mature seeds of several A. salmiana genotypes [2]. Differences of initial seed water uptake in phase I under maximum water availability (Figure 2A) show that $A$. cupreata, which originates from a sub-humid climate (838 $\mathrm{mm}$ annual mean precipitation; Table 2), imbibed more water than species from arid and semi-arid climates (340-361 mm of precipitation) i.e. A. lechuguilla, $A$. americana and A. salmiana. However, this response was not common to all Agave species but was the case for A. striata, with a high water uptake during phase I of germination under the three substrate $\Psi_{\mathrm{W}}$, it possibly can happen as an adaptation to arid habitats ( $287 \mathrm{~mm}$ of precipitation).

Seed water uptake is governed by several variables including seed size and biomass [15], seed-soil $\Psi_{\mathrm{W}}$ difference, seed contact area as affected by vapour or liquid transfer, and conductive properties of the seed for both liquid and vapour phases, among others [12]. In the present study, seeds experienced similar conditions 
Table 2 Agave species used in this study and characteristics of collection sites in Mexico ${ }^{A}$

\begin{tabular}{|c|c|c|c|c|c|}
\hline Subgenera & Species & Collection site & Reproduction & Climate (MAP) $\dagger$ & Type of vegetation \\
\hline \multirow[t]{5}{*}{ Agave } & $\begin{array}{l}\text { A. americana var. } \\
\text { marginata }\end{array}$ & San Luis Potosí, SLP & $\begin{array}{l}\text { Rhizomatous offshoots } \\
\text { and seeds }\end{array}$ & Various (580) & Artificial habitats and ornamental \\
\hline & A. asperrima & Cerritos, San Luis Potosí & $\begin{array}{l}\text { Rhizomatous offshoots } \\
\text { and seeds }\end{array}$ & $\mathrm{BS}_{1} \mathrm{~kW}(450)$ & $\begin{array}{l}\text { Piedmont scrub and xerophytic } \\
\text { shrubland }\end{array}$ \\
\hline & A. duranguensis & Guanajuato, Gto. & $\begin{array}{l}\text { Rhizomatous offshoots } \\
\text { and seeds }\end{array}$ & $\mathrm{BS}_{0} \mathrm{kw}(\mathrm{e})(484)$ & $\begin{array}{l}\text { Xerophytic shrubland, open pine, } \\
\text { and oak forest }\end{array}$ \\
\hline & A. cupreata & Chilapa, Guerrero & Seeds & $A(C) w_{1}(w)\left(i^{\prime}\right) g(838)$ & $\begin{array}{l}\text { Pine and oak forest, pastureland and } \\
\text { palm grove }\end{array}$ \\
\hline & A. salmiana & $\begin{array}{l}\text { La Mantequilla, San Luis } \\
\text { Potosí }\end{array}$ & $\begin{array}{l}\text { Rhizomatous offshoots } \\
\text { and seeds }\end{array}$ & BS1hw(e)g (361) & $\begin{array}{l}\text { Succulent shrubland and mycrophyllous } \\
\text { dry shrubland }\end{array}$ \\
\hline \multirow[t]{2}{*}{ Littaea } & A. lechuguilla & $\begin{array}{l}\text { Guadalcázar, San Luis } \\
\text { Potosí }\end{array}$ & $\begin{array}{l}\text { Rhizomatous offshoots } \\
\text { and seeds }\end{array}$ & $\begin{array}{l}\mathrm{BW} \mathrm{BS}_{0}, \mathrm{BS}_{1} \text { and } \\
\mathrm{CW}_{0}(340)\end{array}$ & Xerophytic rosette shrubland \\
\hline & A. striata & $\begin{array}{l}\text { Guadalcázar, San Luis } \\
\text { Potosí }\end{array}$ & $\begin{array}{l}\text { Seeds and axillary } \\
\text { branching }\end{array}$ & BShw (280) & Xerophytic rosette shrubland \\
\hline
\end{tabular}

A Based on information obtained from CONABIO [16], García [17], Gentry [18], Illsley et. al [19] and Ruiz-Corral et. al [20]. †Mean annual precipitation (mm).

during germination, except substrate $\Psi_{\mathrm{W}}$. Maximum seed water uptake was high in some species with a low seed biomass, but no general correlation between the two variables was noted. A. asperrima and $A$. striata had a low mean seed biomass ( 2 and $5 \mathrm{mg}$; Figure 5 ) and the highest maximum seed water uptake (160\%), but A. americana var. marginata, with one of the larger mean seed biomass $(11 \mathrm{mg})$, had the lowest maximum seed water uptake $(105 \%)$ at $-0.03 \mathrm{MPa}$ (Figures 1A, $2 \mathrm{~B}$ and 5). Differences in maximum seed water uptake among species (Figure 2B) were partly similar to those found by Peña-Valdivia et al. [2] for three A. salmiana genotypes with different seed sizes. We suggest that this result might be evidence for differences in seed water permeability among Agave species. Different ways of water entry into the seed and contrasting sequences of seed structure imbibition among species and cultivars have been previously documented [21,22]. Furthermore, differences in maximum seed water uptake during phase II of germination are due to changes in volume and reorganisation of seed macromolecules (e.g. polysaccharides and proteins) [23] that promote more places on seed for water absorption [24]. During this process, changes within the seed occur at different
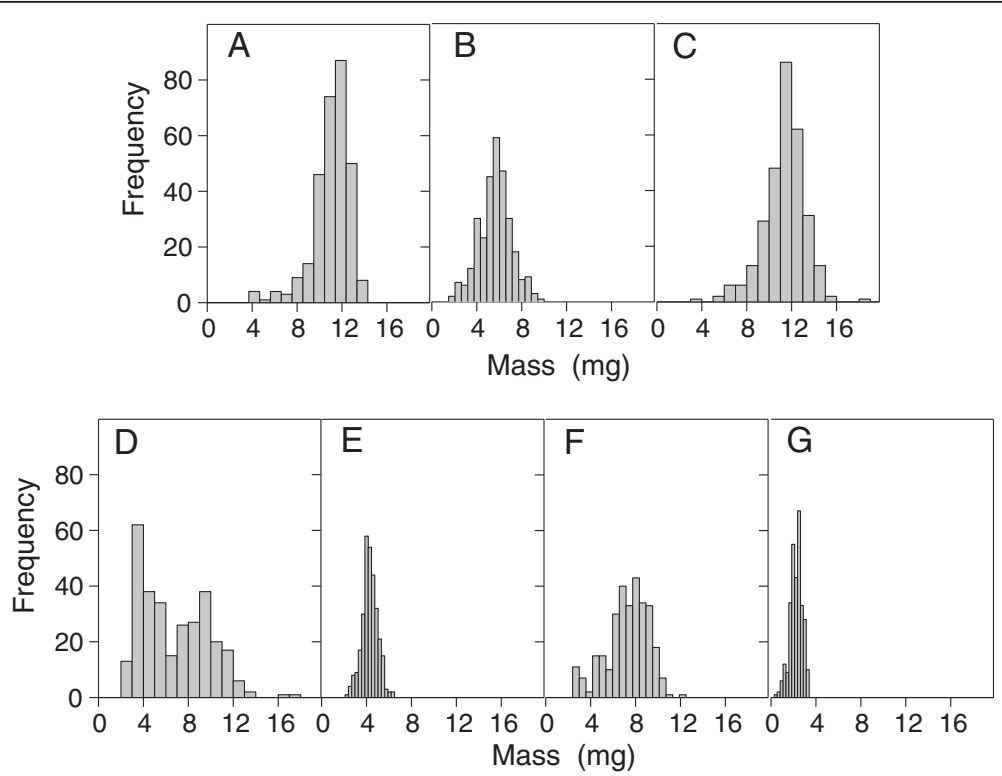

Figure 5 Frequency distribution of seed size (mass) of Agave spp. $\boldsymbol{n}=\mathbf{3 0 0}$. A; A. americana var. marginata, B; A. asperrima, $\mathbf{C} ; A$. cupreata, D; A. duranguensis, $\mathbf{E}$; A. lechuguilla, $\mathbf{F} ;$ A. salmiana and $\mathbf{G} ;$ A. striata. 
rates. Thus, low water availability $\left(\Psi_{\mathrm{W}}\right.$ between -1.0 and $-1.5 \mathrm{MPa}$ ) might promote partial hydration and volume increase of macromolecules in Agave seeds. Despite controversy regarding the role of seed composition in seed water uptake, heterogeneity in maximum seed water uptake between a barley mutant and a cultivar was explained by differences in seed chemical composition [25]. In this context, Brancalion et al. [26] observed a positive relationship between seed protein content and critical seed water content for germination in five Brazilian tropical woody species.

Differences in maximum seed water uptake during phase II of germination in Agave species (Figure 2B) were similar to those for Festuca rubra ssp. litoralis, Lolium perenne and Poa pratensis [27]. Results suggest that Agave seeds at low substrate $\Psi_{\mathrm{W}}$ reached a hydration threshold for radicle emergence. Therefore, more time is required to reach the hydration threshold at low $\Psi_{\mathrm{W}}$ and radicle emergence will not occur [12]. The seed water uptake threshold in most Agave species was approximately half that reached at the highest $\Psi_{\mathrm{W}}$ (Figure 1A-B). This difference was larger than that obtained with seeds of Lolium perenne and $P$. pratensis; seed water uptake to germination in these species diminished from 100 and $90 \%$ to an asymptotic level of 90 and $80 \%$, respectively, when the $\Psi_{\mathrm{W}}$ changed from zero to $-0.8 \mathrm{MPa}$ or less [27].

\section{Radicle emergence}

The lack of dormancy in several Agave species and genotypes has been documented [1,2], as well as the high reproductive effort expressed by semelparity and the production of a huge amount of seeds by a single plant [28]. In contrast, most Agave species in field conditions predominantly present asexual reproduction [29]. The small seed size, which varied between 2 and $11 \mathrm{mg}$ (Figure 5), in relation to the high plant biomass (200 kg estimated for an A. salmiana adult plant), differs from the usual positive correlation found between seed and plant size [30]. However, a lack of dormancy and massive production of small and viable seeds might favour the emergence of a large quantity of seedlings when environmental conditions are favourable, and represent an opportunity for repopulation based on sexual reproduction.

The lowest substrate $\Psi_{\mathrm{W}}$ reduced the maximum accumulated germination of some species $(\mathrm{p}<0.05)$ (Figure 3C). Agave germination at such restrictive substrate $\Psi_{\mathrm{W}}$, under laboratory conditions, might partially mirror the response in the natural environmental conditions where each species grows (Table 2). The low percentage of germination of A. cupreata (20\%) at $-1.5 \mathrm{MPa}$ (Figure 3C) appears to be related to the sub-humid climate $(838 \mathrm{~mm}$ mean annual precipitation) where this species is distributed and contrasts with the non-significant effect of this low $\Psi_{\mathrm{W}}$ on germination of $A$. striata (85\%), A. americana (78\%) and A. lechuguilla (70\%) and the arid and semi-arid climate (280-580 mm mean annual precipitation) within their natural distribution range. Nevertheless, this relationship was not general, as $A$. asperrima reached a very low final cumulative germination (30\%) at $\Psi_{\mathrm{W}}$ of $-1.5 \mathrm{MPa}$, despite originating from a semi-arid climate region $(450 \mathrm{~mm}$ mean annual precipitation).

A lack of germination after $732 \mathrm{~h}$, at $-1.5 \mathrm{MPa}$, suggests that some Agave seeds lack some stimulus for germination, despite the imbibition of a similar amount of water as those seeds already germinating at this specific $\Psi_{\mathrm{W}}$ (Figures 1 and 2). The lack of germination under optimal conditions has been considered as dormancy $[12,31]$, and occurs by a variation of the critical seed $\Psi_{\mathrm{W}}$ to germinate among individual seeds within the same population. Therefore, whereas the seed $\Psi_{\mathrm{W}}$ remains at a partially limiting level, the cumulative germination remains as an asymptote. Inhibition and the absence of germination for some Agave species at -1.0 and $-1.5 \mathrm{MPa}$ (Figure 3B-C) might be evidence of their tolerance to low substrate $\Psi_{\mathrm{W}}$. We recognised $-1.5 \mathrm{MPa}$ as an adequate substrate $\Psi_{\mathrm{W}}$ to identify the effects of water availability on seed germination of Agave spp. and as a stress factor for germination of these species.

The hydrotime model indicates that seeds do not germinate below a $\Psi_{\mathrm{W}}$ threshold, but up to this value, seeds germinate because of $\theta_{\mathrm{H}}$ accumulation. Each seed in a population varies in the threshold level of accumulated $\theta_{\mathrm{H}}$ necessary to germinate, but $\theta_{\mathrm{H}}$ is constant for the population as a whole [11-13]. Repeated measures analysis indicated that accumulation of $\theta_{\mathrm{H}}$ was delayed by the low $\Psi_{\mathrm{W}}$. Also it indicated that germination at $-1.5 \mathrm{MPa}$ significantly increased at 12,24 and $36 \mathrm{~h}$ intervals; whereas at -0.03 and $-1.0 \mathrm{MPa}$ significant increase was observed every 12 or $24 \mathrm{~h}$. Then the $\Psi_{\mathrm{W}}$ threshold was lower than -1.0 MPa for the seven species, but even lower for some of them, as A. striata and A. americana (Figure 3C).

The huge difference in minimum water availability necessary for germination among Agave species was demonstrated by the variation in $\theta_{\mathrm{H}}$ from $137 \mathrm{MPa} \mathrm{h}$ for $A$. duranguensis to $282 \mathrm{MPa}$ h for A. salmiana (Table 1 ). According to Bradford [12], $\theta_{\mathrm{H}}$ is an indicator of seed vigour and physiological quality; results suggested that there was a gradient of vigour among Agave species (Table 1). In general, the hydrotime model adequately fitted data for the germination of Agave spp. (mean $\mathrm{r}^{2}=0.83$ ). However, individual $r^{2}$ values indicated that the hydrotime model better explained seed germination of $A$. asperrima and $A$. lechuguilla than that of $A$. duranguensis and A. salmiana (Table 1 ).

The linear relationship between the rate of Agave seed germination and substrate $\Psi_{\mathrm{W}}$ (Figure 4) was similar to that observed for sugar beet [11] and Eurotia lanata 
(Pursh) Moq. [32]. The rate of Agave seed germination correlated positively with maximum seed water uptake $(\mathrm{r}=0.74, \mathrm{p}<0.05)$; although seeds absorbed more water when water was abundant than when it was restrictive, each seed had a seed water uptake threshold $\left(\Psi_{\mathrm{bg}}\right)$ to initiate germination [13]. The $\Psi_{\mathrm{b}(50)}$ of Agave species (Table 1) was relatively similar to that of Solanum lycopersicum seeds when they were exposed to a low substrate $\Psi_{\mathrm{W}}$, which promoted their germination [33] and was also similar to that of a group of 14 coloniser species [15]. In contrast, higher variation in $\Psi_{\mathrm{b}(50)}$ (from -0.07 to $-5.92 \mathrm{MPa}$ ) was reported by Allen et al. [9] for 24 xerophyte species grouped as species adapted to salinity, sandy soils and diverse habits (generalist species). The $\Psi_{\mathrm{b}(50)}$ has been considered as an indicator of species adaptation to the environment, since salinitytolerant plants had the lowest $\Psi_{\mathrm{b}(50)}$ [9]. The $\Psi_{\mathrm{b}(50)}$, of halophytes [9] and those of A. salmiana, A. americana and $A$. striata (Table 1 ), suggests that germination can occur in conditions of partly dry soil. According to climate data for the distribution regions (Table 2), A. striata, A. lechuguilla and A. salmiana might have less available water than the other species for germination under natural conditions, because the mean annual rainfalls for their habitats are the lowest (287$361 \mathrm{~mm})$. However, maximum accumulated germination and rate of germination at low substrate $\Psi_{\mathrm{W}}, \theta_{\mathrm{H}}$, $\Psi_{\mathrm{b}(50)}$ and their dependence on seed mass appears not to be a distinctive characteristic for these species.

Values of $\Psi_{\mathrm{b}(50)}$ closer to zero for $A$. asperrima and $A$. duranguensis (Table 1 ) indicate that germination might only occur under well-watered soil conditions as Allen et al. [9] observed for sandy soil species; however, results in Figure $3 \mathrm{C}$ indicate a different trend. We presume that both these species might have adapted to germinate during the wet season. Similar findings were observed for S. lycopersicum cultivars, where genetic improvement for tolerance or drought resistance significantly diminished the $\Psi_{\mathrm{b}(50)}$, whereas high values for this variable were characteristic for drought-sensitive cultivars [34].

The similar $\sigma_{\Psi \mathrm{b}}$ among species indicates some degree of seed uniformity; small differences among Agave species in Table 1 might result from partial homogeneity of seed size (mass) among the species, because seeds used in the study were restricted to a seed biomass within one $\sigma$ range of the total sample of each Agave species (Figure 5). The large $\sigma_{\Psi \mathrm{b}}$ for $A$. salmiana could be interpreted as a high ecological plasticity, as $\Psi_{\mathrm{bg}}$ is more variable, and these seeds might germinate under widely variable water conditions (Figure 3). Germination of A. salmiana in extreme environmental conditions, such as high temperature, was recently reported [1].

\section{Recovery of germination}

Seeds of most Agave species remained imbibed for more than $30 \mathrm{~d}$ with $70 \%$ hydration without damage (Figure 3C). The ability of these seeds to remain partially hydrated without germination has been considered as a type of dormancy and appears to be an appropriate response to arid and semi-arid environments, since if germination occurs at very low substrate $\Psi_{\mathrm{W}}$ seedling survival will decrease [31]. This seed tolerance appears to be associated with the so-called "seed hydration memory" of several desert Cactaceae by Dubrovsky [35,36].

All these results confirm that Agave seeds can germinate under adverse environment [1,2] but with some diverse responses to the natural environment among species. It has been reported that sexual reproduction of Agave spp. plants is unusual in the wild [28], therefore, it is necessary to study the repopulation process in the field.

\section{Conclusions}

Several Agave species lack seed dormancy independently of species distribution. Agave species reach about half the maximum seed water uptake under low water availability compared with well-watered substrates and most of them reach more than 50\% germination. Several Agave species can maintain low seed water uptake for several weeks and germinate rapidly when water availability increases. Germination responses of Agave species from dry climate suggest adaptation to low water availability. Seed biomass do not appears to be a distinctive characteristic for responses to water availability during germination.

\section{Methods}

\section{Plant material}

Seven Mexican Agave species were studied, which all had ancestral or current economic importance and belonged to different geographical distributions with different climates, and had sexual or asexual (or both) reproduction strategies or diverse systematic positions (Table 2). Fruits from vigorous healthy plants were harvested and dried under laboratory conditions $\left(25^{\circ} \mathrm{C}\right.$ and low relative humidity). To standardise seed water content, seeds of each species were placed in a cheesecloth-like bag inside a glass jar three months prior to experimentation and maintained at $4 \pm 1^{\circ} \mathrm{C}$. Subsequently, four replicates, each with five seed, were used to measure seed water content, which was $7.62 \pm 0.52 \%$.

\section{Seed biomass stratification}

Seed biomass was obtained from a sample of 300 seeds from each species (Figure 5). Because variation in seed biomass within a species might affect germination, only seeds within one standard deviation of the mean seed 
biomass for each species were used [1]. Agave duranguensis showed a bimodal seed size distribution; a preliminary assay of germination showed little or no germination of lighter seeds, therefore, heavier seeds of this species were used for this study.

\section{Substrate water potential and experimental conditions}

Vermiculite was rinsed in tap water and then dried at $100^{\circ} \mathrm{C}$ to constant weight. Three different vermiculite $\Psi_{\mathrm{W}}(-0.03,-1.0$ and $-1.5 \mathrm{MPa})$ were obtained by mixing $100 \mathrm{~g}$ dry vermiculite with 170, 16 or $11 \mathrm{~mL}$ distilled water (w:v) in polyethylene bags. These were sealed for $48 \mathrm{~h}$ before the start of the assay, according to Peña-Valdivia and Sánchez-Urdaneta [6], after which time a vermiculite sample was incubated in a psychrometric chamber (Wescor C-52, Inc, Utha, USA) for $4 \mathrm{~h}$, and its $\Psi_{\mathrm{W}}$ was subsequently determined by connecting the chambers to a microvoltmeter (Wescor HR-33 T, Inc, Utha, USA) operated in the dew-point mode.

Individual seeds were sown at $1 \mathrm{~cm}$ depth in cylindrical polyvinyl chloride (PVC) containers (40 mm diameter, $50 \mathrm{~mm}$ depth). Containers were filled with vermiculite at each $\Psi_{\mathrm{W}}$ and sealed with a piece of black polyethylene, which was fixed with an elastic band to keep constant $\Psi_{\mathrm{W}}$ and were kept in the dark at $25 \pm 2{ }^{\circ} \mathrm{C}$.

\section{Data recording and analysis}

Seed water uptake (expressed as a percentage of initial seed biomass) and seed germination were recorded every $12 \mathrm{~h}$ or daily up to maximum values. Germination was considered to have occurred when the emerging root was at least $5 \mathrm{~mm}$ long and maximum germination in each treatment was determined when no additional seeds germinated after 3-4 days. Vermiculite from each experimental unit was renewed every $72 \mathrm{~h}$ to maintain a constant substrate $\Psi_{\mathrm{W}}$. When treatments at $-1.5 \mathrm{MPa}$ had reached maximum germination, non-germinated seeds were transferred to vermiculite at $-0.03 \mathrm{MPa}$ and kept until germination occurred or seed damage appeared.

Germination attributes were analysed using the hydrotime model. According to this model [11-13], seed germination can be described using the following equation:

$$
\Psi_{\mathrm{bg}}=\Psi_{\mathrm{w}^{-}}-\left(\theta_{\mathrm{H}} / \mathrm{tg}_{\mathrm{g}}\right)
$$

where $\Psi_{b g}$ was the base water potential (MPa) at which the $g$ seed sample germinates, $\Psi_{\mathrm{W}}$ was the substrate water potential $(\mathrm{MPa}), \theta_{\mathrm{H}}$ was the hydrotime constant, or the accumulated water-time required to germinate a one g sample of a seed population $(\mathrm{MPa} h)$, and $t_{g}$ was the time from water uptake until germination of the $g$ fraction (h or d). It was assumed that $\Psi_{\text {bg }}$ was normally distributed within a seed population, and that $\theta_{\mathrm{H}}$ was constant for all seed fractions [13]. Apart from seed $\Psi_{\mathrm{bg}}$, the median population $\Psi_{\mathrm{bg}}$ can be estimated $\left(\Psi_{\mathrm{b}(50)}\right)$ and was defined as the base or minimum $\Psi_{\mathrm{W}}$ necessary to achieve $50 \%$ germination. At this level of germination, it was possible to quantify the time taken for $50 \%$ germination $\left(t_{50}\right)$ or the rate of germination $\left(1 / t_{50}\right)$. The standard deviation $\left(\sigma_{\Psi \mathrm{b}}\right)$ of $\Psi_{\mathrm{b}(50)}$ was the parameter of $\Psi_{\mathrm{bg}}$ variability. The hydrotime parameters were calculated as described by Allen et al. [9].

\section{Experimental design and statistical analysis}

This study was conducted using a completely randomised design, with a factorial $(7 \times 3)$ arrangement of treatments and five experimental units; each unit was a group of 10 PVC containers. Factors were species $(A$. americana var. marginata, A. asperrima, A. cupreata, $A$. duranguesis, A. lechuguilla, $A$. salmiana and $A$. striata) and substrate $\Psi_{\mathrm{W}}(-0.03,-1.0$ and $-1.5 \mathrm{MPa})$. The normality test was performed based on graphic residual analysis and the Shapiro-Wilks test for data for initial and maximum seed water uptake, rate of germination $\left(1 / t_{50}\right)$ and the maximum accumulated percentage of germination at every time. Data were transformed when normality supposition failed. Variables were analysed using the GLM procedure of SAS software, 9.17 version (SAS Institute, NC, USA) and significant differences among treatment means were established using Tukey's honest significant difference (HSD) test with $\alpha=0.05$.

A repeated measurements test was performed in order to analyse variation of cumulatove germination along the time. For this analysis Statistica Ver. 6 software was used.

\section{Competing interests}

The authors declare that they have no competing interests.

\section{Authors' contributions}

HMR-T carried out the experiments and drafted the first version of the manuscript. CBP-V directed the study, contributed to drafting the manuscript and deepened the discussion. CT improved the experimental design and deepened the discussion. JRA collected part of the seed materials and improved the experimental design. HV supported data analysis. All authors read and approved the final manuscript.

\section{Acknowledgements}

The authors thank the Grupo de Estudios Ambientales for kindly providing A cupreata seeds. The Consejo Nacional de Ciencia y Tecnología (México) provided a scholarship to the first author for doctoral studies. Dr. Salvador Valle facilitated laboratory access for conducting part of the assays.

\section{Author details}

${ }^{1}$ Facultad de Agronomía, Universidad Autónoma de San Luis Potosí, Carretera San Luis Potosí - Matehuala km 14.5, Ejido Palma de la Cruz, Soledad de Graciano Sánchez, San Luis Potosí 78321, México. ${ }^{2}$ Botánica, Campus Montecillo, Colegio de Postgraduados, Carretera México-Texcoco km 36.5, Texcoco, Estado de México CP 56230, México. ${ }^{3}$ Instituto de Investigación de Zonas Desérticas, Universidad Autónoma de San Luis Potosí, Altaír 200, Fraccionamiento del Llano, San Luis Potosí, SLP CP 78377, México. ${ }^{4}$ Estadística, Campus Montecillo, Colegio de Postgraduados, Carretera México-Texcoco km 36.5, Texcoco, Estado de México CP 56230, México. 
Received: 1 July 2013 Accepted: 30 December 2013

Published: 1 April 2014

\section{References}

1. Ramírez-Tobías HM, Peña-Valdivia CB, Aguirre JR, Reyes-Agüero JA, Sánchez-Urdaneta $A B$, Valle-Guadarrama $S$ : Seed germination temperatures of eight Mexican Agave species with an extensive history of human use. Plant Species Biol 2012, 27:124-137.

2. Peña-Valdivia CB, Sánchez-Urdaneta AB, Aguirre JR, Trejo C, Cárdenas E, Villegas A: Temperature and mechanical scarification on seed germination of 'maguey' (Agave salmiana Otto ex Salm-Dyck). Seed Sci Technol 2006, 34:47-56.

3. Valenzuela-Zapata AG, Nabhan GP: Tequila. A natural and cultural history. Tucson: The University of Arizona Press; 2003:114.

4. García-Mendoza A: Los agaves de México. Ciencias 2007, 87:14-23.

5. García-Moya E, Romero-Manzanares A, Nobel PS: Highlights for Agave productivity. Global Change Biol Bioenerg 2011, 3:4-14.

6. Peña-Valdivia $C B$, Sánchez-Urdaneta $A B$ : Effects of substrate water potential in root growth of Agave salmiana Otto ex Salm-Dyck seedlings. Biol Res 2009, 42:239-248.

7. Pimienta-Barrios E, Robles-Murguía C, Nobel PS: Net $\mathrm{CO}_{2}$ uptake for Agave tequilana in a warm and temperate environment. Biotropica 2001, 33:312-318.

8. Ruiz GS, Peña-Valdivia CB, Trejo C, Sánchez A: Reacción fisiológica del maguey (Agave salmiana Otto ex Salm-Dyck) a la sequía intermitente. Rev Fac Agron LUZ 2007, 24:318-325.

9. Allen PS, Meyer SE, Khan MA: Hydrothermal time as a tool in comparative germination studies. In Seed Biology: Advances and Applications. Edited by Black M, Bradford KJ, Vazquez-Ramos J. Wallingford: CAB International; 2000:401-410.

10. Sadeghian SY, Yavari N: Effect of water-deficit stress on germination and early seedling growth in sugar beet. J Agron Crop Sci 2004, 190:138-144.

11. Gummerson RJ: The effect of constant temperatures and osmotic potentials on the germination of sugar beet. J Exp Bot 1986, 37:729-741.

12. Bradford KJ: Water relations in seed germination. In Seed Development and Germination. Edited by KIGEL J, GALILI G. New York: Marcel Dekker; 1995:351-396.

13. Bradford $\mathrm{KJ}$ : Applications of hydrothermal time to quantifying and modelling seed germination and dormancy. Weed Sci 2002, 50:248-260.

14. Köchy M, Tielbörger $\mathrm{K}$ : Hydrothermal time model of germination: Parameters for 36 Mediterranean annual species based on a simplified approach. Basic Appl Ecol 2007, 8:171-182

15. Daws MI, Crabtree LM, Dalling JW, Mullins CE, Burslem DFRP: Germination responses to water potential in neotropical pioneers suggest large-seeded species take more risks. Ann Bot 2008, 102:945-951.

16. CONABIO: Mezcales y Diversidad. 2nd edition. México, DF: Comisión Nacional para el Conocimiento y Uso de la Biodiversidad (map); 2006.

17. García E: Modificaciones al sistema de clasificación climática de Köppen. 5ath edition. México, DF: Instituto de Geografía, UNAM; 2004.

18. Gentry HS: Agaves of Continental North America. Tucson: The University of Arizona Press; 1982.

19. Illsley C, Vega E, Pisanty I, Tlacotempa A, García P, Montes P, Rivera G, García J, Jiménez V, Castro F, Calzada M: Maguey papalote: hacia el manejo sustentable de un recurso colectivo en el trópico seco de Guerrero México. In En lo Ancestral hay Futuro: del Tequila, los Mezcales y otros Agaves. Edited by Colunga-Garcíamarín P, Larqué A, Eguarte LE, Zizumbo-Villareal D. México: Centro de Investigación Científica de Yucatán; 2007:319-338.

20. Ruiz-Corral JA, Pimienta-BarrioS E, Zañudo-Hernández J: Optimal and marginal thermal regions for the cultivation of Agave tequilana on the Jalisco state. Agrociencia 2002, 36:41-53

21. Kikuchi K, Koizumi M, Ishida N, Kano H: Water uptake by dry beans observed by micro-magnetic resonance imaging. Annals Bot 2006, 98:545-553.

22. Koizumi M, Kikuchi K, Isobe S, Ishida N, Naito S, Kano H: Role of seed coat in imbibing soybean seeds observed by micro-magnetic resonance imaging. Ann Bot 2008, 102:343-352.

23. Meyer CJ, Steudle E, Peterson CA: Patterns and kinetics of water uptake by soybean seeds. J Exp Bot 2007, 58:717-732

24. Vertucci CW: The kinetics of seed imbibition: Controlling factors and relevance to seedling vigor. In Seed Moisture. Edited by Stanwood PC, Mcdonald MB. Madison: CSSA Crop Science Society of America; 1989:93-115.
25. Molina-Cano JL, Sopena A, Polo JP, Bergareche C, Moralejo MA, Swanson JS, Glidewell SM: Relationships between barley hordeins and malting quality in a mutant of cv. Triumph. II. Genetic and environmental effects on water uptake. J Cereal Sci 2002, 36:39-50.

26. Brancalion PHS, Novembre ADLC, Rodrigues RR, Tay D, Cunha LC: Seed imbibition of five Brazilian native tree species. Acta Horticulturae 2008, 771:77-81.

27. Larsen SU, Bailly C, Côme D, Corbineau F: Use of the hydrothermal time model to analyse interacting effects of water and temperature on germination of three grass species. Seed Sci Res 2004, 14:35-50.

28. Arizaga S, Ezcurra E: Propagation mechanisms in Agave macroacantha (Agavaceae), a tropical arid land succulent rosette. Am J Bot 2002, 89:632-641.

29. Eguiarte LE, Souza V: Historia natural del Agave y sus parientes silvestres; Evolución y Ecología. In En lo Ancestral hay Futuro: del Tequila, los Mezcales y otros Agaves. Edited by Colunga-Garcíamarín P, Larqué A, Eguarte LE Zizumbo-villareal D. México: Centro de Investigación Científica de Yucatán: 2007:3-21

30. Moles AT, Falster DS, Leishman MR, Westoby M: Small-seeded species produce more seeds per square meter of canopy per year, but not per individual per lifetime. J Ecol 2004, 92:384-396.

31. Hegarty TW: The physiology of seed hydration and dehydration, and the relation between water stress and the control of germination: a review. Plant Cell Environ 1978, 1:101-119.

32. Wang $R$, Bai $Y$, Tanino K: Germination of winterfat (Eurotia lanata (Pursh) Moq.) seeds at reduced water potentials: testing assumptions of hydrothermal time model. Environ Exper Bot 2005, 53:49-63.

33. Ni BR, Bradford KJ: Quantitative models characterizing seed germination responses to abscisic acid and osmoticum. Plant Physiol 1992, 98:1057-1068.

34. Dahal P, Bradford KJ: Hydrothermal time analysis of tomato seed germination at suboptimal temperature and reduced water potential. Seed Sci Res 1994, 4:71-80.

35. Dubrovsky JG: Seed hydration memory in Sonoran Desert cacti and its ecological implication. Amer J Bot 1996, 83:624-632.

36. Dubrovsky JG: Discontinuous hydration as a facultative requirement for seed germination in two cactus species of the Sonoran Desert. J Torrey Bot Soc 1998, 125:33-39.

doi:10.1186/0717-6287-47-11

Cite this article as: Ramírez-Tobías et al:: Seed germination of Agave species as influenced by substrate water potential. Biological Research 2014 47:11

\section{Submit your next manuscript to BioMed Central and take full advantage of:}

- Convenient online submission

- Thorough peer review

- No space constraints or color figure charges

- Immediate publication on acceptance

- Inclusion in PubMed, CAS, Scopus and Google Scholar

- Research which is freely available for redistribution

Submit your manuscript at www.biomedcentral.com/submit
C Biomed Central 